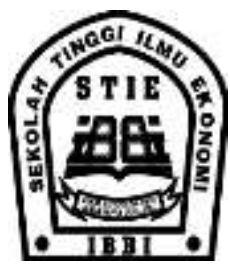

ISSN 1858-3202

JURNAL

BINA AKUNTANSI

IBBI

\title{
ANALISIS PENGARUH RASIO KEUANGAN TERHADAP PERTUMBUHAN LABA PADA PERUSAHAAN MANUFAKTUR YANG TERDAFTAR DI BURSA EFEK INDONESIA
}

\author{
Boy Fadly \\ Akuntansi, STIE IBBI
}

\begin{abstract}
This study is purposed, to examine whether the financial ratios affect either partially or simultaneously to earnings growth cash of the company manufacturing listed in Indonesia Stock Exchange 2010 - 2012. This study used a purposive sampling method. The conclusion that can be drawn from the test results that partially affect the net profit margin has an effect on earnings growth. While simultaneously debt to assets ratio, net profit margin, working capital to total asset, and inventory turnover have an effects earnings growth.
\end{abstract}

Key Words : Earnings Growth, Financial Ratios, Indonesia Stock Exchange

\section{PENDAHULUAN}

\section{Latar Belakang Penelitian}

Tujuan perusahaaan pada umumnya adalah untuk memaksimalkan perolehan laba usaha dengan maksud untuk kelangsungan hidup perusahaan. Laba yang diperoleh perusahaan merupakan kenaikan manfaat ekonomi selama satu periode akuntansi dalam bentuk penerimaan atau penambahan aktivitas atau penurunan kewajiban yang mengakibatkan kenaikan ekuitas yang tidak berasal dari kontribusi penanaman modal. Laba yang diperoleh perusahaan dari kegiatan transaksi selama satu periode akuntansi pada dasarnya digunakan sebagai salah satu ukuran prestasi yang dicapai perusahaan, dimana laba yang diperoleh dapat dijadikan sebagai pedoman dalam pengambilan keputusan investasi dan prediksi untuk meramalkan pertumbuhan laba di masa mendatang. Laba yang akan diperoleh perusahaan di masa mendatang tidak dapat dipastikan, maka diperlukan adanya prediksi pertumbuhan laba. Dalam mecapai tujuannya, pengelolaan perusahaan harus dilakukan sebaik mungkin agar dapat menjadi perusahaan yang mampu bersaing dengan perusahaan yang lain. Wujud dari pengelolaan perusahaan yang baik dapat dilihat dari kinerja perusahaan, salah satunya dapat dinilai melalui pertumbuhan laba. Apabila kinerja perusahaan baik maka pertumbuhan laba meningkat, begitu juga sebaliknya apabila kinerja perusahaan tidak baik maka pertumbuhan laba akan meurun.

Pertumbuhan laba merupakan kenaikan atau penurunan laba yang dihasilkan perusahaan yang terjadi dari tahun ke tahun. Pertumbuhan laba perusahaan dapat dilihat melalui kenaikan laba dari tahun sebelumnya pada laporan keuangan sehingga laporan keuangan harus dapat menjelaskan informasi yang jelas. Cara untuk mengevaluasi dan menginterpretasikan data laporan keuangan adalah melalui analisis rasio keuangan rasio keuangan berguna untuk mengidentifikasi kekuatan dan kelemahan keuangan suatu perusahaan dan memungkinkan sebagai investor menilai kondisi keuangan dan hasil operasi perusahaan saat ini dan masa lalu, serta sebagai pedoman bagi investor mengenai kinerja masa lalu dan masa mendatang yang dapat dimanfaatkan dalam pengambilan keputusan investasinya.

Penelitian ini merupakan replikasi dari penelitian yang dilakukan oleh Tika (2011) yang menggunakan lima rasio keuangan yaitu quick ratio, debt ratio, inventory turnover, net income to sales, dan gross profit margin. 


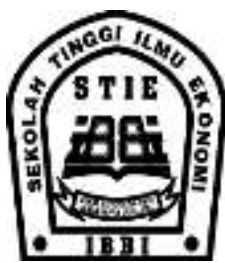

Sedangkan rasio keuangan yang digunakan dalam penelitian ini adalah debt to asset ratio, net profit margin, working capital to total assets, dan inventory turnover.

\section{TINJAUAN LITERATUR}

\section{Pertumbuhan Laba}

Pertumbuhan laba merupakan perbedaan antara pendapatan yang direalisasi yang timbul dari transaksi selama satu periode dengan biaya yang berkaitan dengan pendapatan. Laba merupakan kenaikan manfaat ekonomi selama satu periode akuntansi dalam bentuk pemasukan atau penambahan aktiva atau penurunan kewajiban yang mengakibatkan kenaikan ekuitas yang tidak berasal dari kontribusi penanaman modal. Kinerja perusahaan merupakan hasil dari serangkaian proses dengan mengorbankan berbagai sumber daya. Salah satu parameter penilaian kierja perusahaan adalah pertumbuhan laba. Adapun taktor yang mempengaruhi pertumbuhan laba :

1. Besarnya perusahaan, semakin besar perusahaan maka pertumbuhan laba akan semakin tinggi.

2. Umur perusahaan, perusahaan yang baru berdiri kurang memiliki pengalaman dalam meningkatkan laba sehingga pendapatan laba masih rendah.

3. Tingkat leverage, jika perusahaan memiliki tingkat hutang yang tinggi, maka manejer cenderung memanipulasi laba sehingga dapat mengurangi ketepatan pertumbuhan laba.

4. Tingkat penjualan, semakin tinggi tingkat penjualan yang diperoleh, maka pertumbuhan laba akan semakin tinggi.

5. Perubahan laba masa lalu, semakin besar perubahan laba masa lalu, maka semakin tidak pasti laba yang diperoleh di masa mendatang.

Pertumbuhan laba adalah kenaikan atau penurunan laba yang dihasilkan perusahaan yang terjadi dari tahun ke tahun. Pertumbuhan laba merupakan selisih laba tahun yang diteliti dengan laba tahun sebelumnya yang kemudian dibandingkan dengan laba tahun sebelumnya. Pertumbuhan laba dapat dihitung dengan cara :

$$
\Delta \mathrm{Y}=\frac{\mathrm{Y}_{\mathrm{t}}-\mathrm{Y}_{\mathrm{t}-1}}{\mathrm{Y}_{\mathrm{t}-1}}
$$

\section{Debt to Asset Ratio}

Solvabilitas suatu perusahaan menunjukkan kemampuan perusahaan untuk memenuhi segala kewajiban finansialnya apabila sekiranya perusahaan tersebut pada saat itu dilikuidasikan. DRA merupakan salah satu rasio yang digunakan untuk mengukur solvabilitas suatu perusahaan. Rasio ini berguna untuk menilai utang dengan aktiva.

Semakin tinggi nilai DAR maka semakin tinggi resiko kerugian yang dihadapi, karena perusahaan harus memberikan return kepada kreditur atas pinjaman yang dilakukan, tetapi perusahaan juga mempunyai kesempatan yang tinggi untuk memperoleh laba dalam memanfaatkan pinjaman tersebut dalam kegiatan usahanya. Sebaliknya, apabila nilai DR rendah maka resiko kerugian akan lebih kecil, tetapi return yang akan diperoleh kreditur juga semakin kecil. Oleh karena itu, suatu perusahaan harus lebih teliti dalam hal pemberian return, dengan tujuan akan memperoleh laba yang diharapkan. DR dapat dihitung dengan membandingkan antara jumlah utang dengan jumlah aktiva.

$$
\text { Debt to Asset Ratio }=\frac{\text { Total Hutang }}{\text { Total Aktiva }}
$$

\section{Net Profit Margin}

NPM sebagai bagian dari rasio profitabilitas merupakan sebuah alat analisis untuk mengetahui kemampuan perusahaan menghasilkan laba pada tingkat penjualan tertentu. NPM juga diinterpretasikan sebagai tingkat efisiensi perusahaan, sejauh mana perusahaan dapat meminimalkan biaya-biaya yang timbul dan memaksimalkan laba. Semakin tinggi nilai NPM, maka semakin efektif suatu perusahaan dalam menjalankan operasinya, dengan demikian pertumbuhan laba suatu perusahaan juga akan semakin meningkat. NPM 


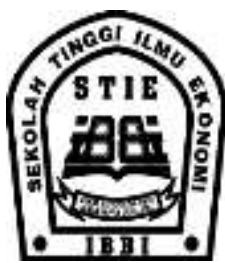

dapat dihitung dengan membandingkan laba bersih dengan penjualan bersih.

Net Profit Margin $=\frac{\text { Laba Bersih Setelah Pajak }}{\text { Penjualan Bersih }}$

\section{Working Capital to Total Assets}

WCTA menunjukkan potensi cadangan kas yang ada akibat selisih yang terjadi antara aktiva lancar dengan kewajiban lancar. WCTA digunakan untuk mengukur likuiditas dari total aktiva dan posisi modal kerja.

Aset lancar adalah aset yang diharapkan perusahaan dapatkan dalam waktu dekat. Modal kerja mengukur potensi cadangan perusahaan secara kasar. WCTA yang semakin tinggi menunjukkan modal operasional perusahaan besar dibandingkan dengan jumlah aktivanya. Modal kerja yang besar akan memperlancar kegiatan operasi perusahaan sehingga perusahaan mampu membayar hutangnya, dengan demikian pendapatan yang diperoleh meningkat. Semakin besar WCTA akan meningkatkan laba selanjutnya dan mempengaruhi peningkatan pertumbuhan laba.

Rasio ini juga dapat digunakan sebagai alat diskriminan dalam menentukan suatu kebangkrutan. Karakteristik likuiditas benarbenar ditentukan secara jelas dikarenakan sebuah perusahaan yang mengalami kerugian operasi yang terus-menerus akan menyusutkan aktiva lancar sehubungan dengan total aktiva. Di antara penilaian terhadap rasio ikuiditas, rasio ini terbukti paling berharga.

Working Capital to Total Assets $=\frac{\text { Aktiva Lancar }- \text { Kewajiban Lancar }}{\text { Total Aktiva }}$

\section{Inventory Turnover}

IT atau perputaran persediaan adalah suatu ukuran yang menunjukkan berapa kali perputaran persediaan dalam satu tahun. Apabila tingkat perputaran tinggi maka tingkat penjualannya juga tinggi, sehingga pendapatan dan laba operasi juga akan meningkat. Sebaliknya jika tingkat perputaran rendah, maka penjualannya juga rendah yang akan mengakibatkan penurunan pendapatan dan berdampak pada penurunan laba operasi karena timbulnya biaya tambahan yang harus dikeluarkan oleh perusahaan, seperti biaya pemeliharaan dan penyimpanan persediaan.

Semakin tinggi IT semakin cepat juga pertumbuhan laba yang akan diperoleh suatu perusahaan dengan meningkatkan perputaran persediaan. Cara menghitung adalah dengan membandingkan jumlah harga pokok penjualan dengan jumlah persediaan.

$$
\begin{aligned}
& \text { Inventory Turnover }=\frac{\text { Harga Pokok Penjualan }}{\text { Total Persediaan }} \\
& \text { 3. KERANGKA BERPIKIR }
\end{aligned}
$$

\section{KERANGKA BERPIKIR}

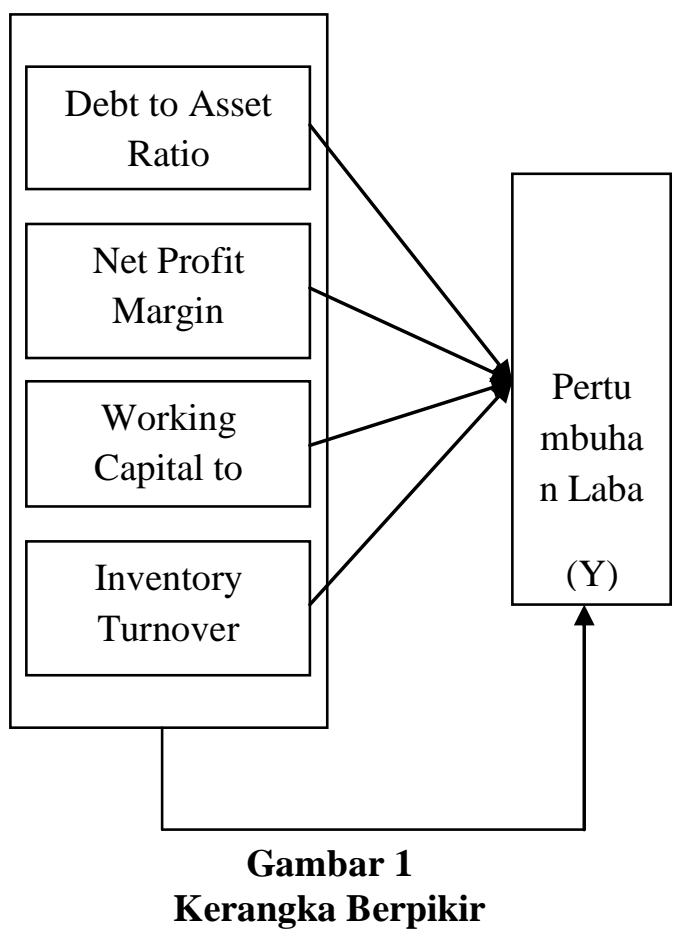

Debt to Asset Ratio menunjukkan kemampuan perusahaan dalam melunasi utangutangnya. Perusahaan dapat menghilangkan resiko ketidaksanggupan membayar pinjaman dengan tidak melakukan pinjaman ke luar, tetapi hal ini akan menyebabkan kecilnya keuntungan yang dapat diperoleh perusahaan karena seluruh dananya berasal dari ekuitas. Dengan demikian, DAR dapat mempengaruhi pertumbuhan laba sebab dana yang berasal dari 


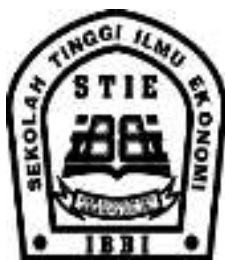

kreditur dapat digunakan dalam kegiatan operasional untuk memperoleh laba.

Net Profit Margin sebagai alat untuk mengukur kemampuan perusahaan dalam menghasilkan laba bersih dari jumlah penjualan. Kemampuan manajemen perusahaan dalam menempatan dana juga dapat dilihat dari rasio ini. Sebab NPM berkaitan dengan peningkatan penjualan, meminimalkan beban, dan ketentuan besarnya pajak. Semakin besar rasio ini, maka semakin tepat pula penempatan dana yang dilakukan perusahaan karena laba yang dihasilkan juga semakin tinggi.

Working capital to total assets meunjukkan potensi cadangan kas yang ada akibat selisih yang terjadi antara aktiva lancar dengan kewajiban lancar. Modal kerja yang dimaksud di sini adalah modal kerja bersih, yaitu bagian dari aktiva lancar yang benar-benar dapat digunakan untuk membiayai operasi perusahaan. Dengan modal kerja yang besar, kegiatan operasional perusahaan dapat berjalan lancar dan diharapkan laba yang diperoleh perusahaan juga meningkat. Sehingga WCTA yang tinggi juga mengindikasikan pertumbuhan laba yang tinggi.

Inventory turnover menunjukkan berapa kali perputaran persediaan dalam satu tahun. Semakin banyak persediaan yang dijual maka secara langsung penjualan juga semakin tinggi dan berbanding lurus juga dengan meningkatnya laba. Dengan demikian IT berpengaruh terhadap pertumbuhan laba. Rasio ini hanya dapat dibandingkan diantara perusahaan yang sejenis karena karakteristik perputaran persediaan perusahaan yang dibandingkan harus sama.

\section{METODOLOGI PENELITIAN}

Penelitian ini dilakukan sekitar bulan Januari-Juni 2014 pada perusahaan manufaktur yang terdaftar di Bursa Efek Indonesia. Populasi yang digunakan dalam penelitian ini adalah perusahaan manufaktur yang terdaftar di Bursa Efek Indonesia periode 2010-2012 yang berjumlah 137 perusahaan. Sampel yang dipilih dalam penelitian ini menggunakan metode purposive sampling, yaitu pemilihan sampel berdasarkan kriteria tertentu. Maka perusahaan yang menjadi sampel dalam penelitian ini berjumlah 64 perusahaan, dalam jangka waktu penelitian 3 tahun sehingga banyak data pengamatan adalah 192 data pengamatan (64x3).

Teknik analisa data yang digunakan adalah analisis regresi berganda setelah memenuhi asumsi klasik menyangkut uji normalitas, multikolinearitas, heteroskedastisitas dan autokorelasi. Penarikan kesimpulan atas hipotesis dilakukan dengan cara uji t dan uji $\mathrm{F}$ pada level signifikansi 5\%. Keseluruhan tabulasi dan pengelolaan data menggunakan software SPSS versi 18.

\section{HASIL PENELITIAN}

\section{Hasil Statistik Deskriptif}

Statistik deskriptif memberikan penjelasan mengenai nilai minimum, nilai maksimum, nilai rata-rata (Mean), nilai standar deviasi data yang digunakan dalam penelitian.

a. Variabel debt to asset ratio memiliki nilai minimum pada PT Pelangi Indah Canindo, Tbk sebesar 0.00, nilai maksimum pada PT Ever Shine Tex, Tbk sebesar 1.78, nilai rata-rata sebesar 0.4627, dan standar deviasi sebesar 0.22944 yang dimiliki seluruh perusahaan dengan jumlah pengamatan sebanyak 192 .

b. Variabel net profit margin memiliki nilai minimum pada PT Multistrada Arah Sarana, Tbk sebesar -6.91, nilai maksimum pada PT Budi Acid Jaya, Tbk sebesar 0.80, nilai rata-rata sebesar -2.9169 , dan standar deviasi sebesar 1.13491 yang dimiliki seluruh perusahaaan dengan jumlah pengamatan sebanyak 192 .

c. Variabel working capital to total assets memiliki nilai minimum pada PT Schering Plough Indonesia, Tbk sebesar 0.10, nilai maksimum pada PT Indomobil Sukses International, Tbk sebesar 4.59, nilai rata- 
rata sebesar 3.5519, dan standar deviasi sebesar 0.65261 yang dimiliki seluruh perusahaan dengan jumlah pengamatan sebanyak 192.

d. Variabel inventory turnover memiliki nilai minimum pada PT Schering Plough Indonesia, Tbk sebesar 0.17, nilai maksimum pada PT Alkasa Industrindo, Tbksebesar 4.53, nilai rata-rata sebesar 2.6341, dan standar deviasi sebesar 1.20367 yang dimiliki seluruh perusahaan dengan jumlah pengamatan sebanyak 192.

e. Variabel pertumbuhan laba memiliki nilai minimum pada PT Astra International,Tbk sebesar 0,00, nilai maksimum pada PT Tiga Pilar Sejahtera Food, Tbk sebesar 1.69, nilai rata-rata sebesar 0.4298, dan standar deviasi sebesar 0.28895 yang dimiliki seluruh perusahaan dengan jumlah pengamatan sebanyak 192.

\section{Hasil Uji t}

Pengujian hipotesis secara parsial (individu) dengan menggunakan "uji t" yaitu dengan melihat tingkat signifikansi dibandingkan dengan 0.05. Pengujian ini dilakukan untuk membuktikan apakah pengaruh dari variabel independen secara parsial (individu) memiliki pengaruh signifikan atau tidak dengan variabel dependen.

1. Debt to asset ratio (LN_DAR) mempunyai nilai signifikansi sebesar 0.598 yang berarti nilai ini lebih besar dari 0.05 sehingga hipotesis tidak diterima, Artinya, debt to asset ratio tidak berpengaruh terhadap pertumbuhan laba.

2. Net profit margin (LN_NPM) mempunyai nilai signifikansi sebesar 0.030 yang berarti nilai ini lebih kecil dari 0.05 sehingga hipotesis diterima, Artinya, net profit margin berpengaruh terhadap pertumbuhan laba.
3. Working capital to total assets (LN_WCTA) mempunyai nilai signifikansi sebesar 0.812 yang berarti nilai ini lebih besar dari 0.05 sehingga hipotesis ditolak, Artinya, working capital to total assets tidak berpengaruh terhadap pertumbuhan laba.

4. Inventory Turnover (LN_IT) mempunyai nilai signifikansi sebesar 0.116 yang berarti nilai ini lebih besar dari 0.05 sehingga hipotesis ditolak, Artinya, inventory turnover tidak berpengaruh terhadap pertumbuhan laba.

\section{Hasil Uji F}

Secara simultan, pengujian hipotesis dilakukan dengan uji $\mathrm{F}$ ( $F$ test $)$ yaitu dengan melihat tingkat signifikansi dibandingkan dengan 0.05. Uji $\mathrm{F}$ dilakukan untuk menguji apakah variabel-variabel independen berpengaruh secara simultan terhadap variabel independen. Diperoleh p- value $0.000<0.05$, artinya signifikan. Hal ini menunjukkan bahwa $\mathrm{H}_{5}$ diterima, sehingga dapat disimpulkan bahwa semua variabel independen yaitu debt to assets ratio, net prfit margin, working capital to total asset, dan inventory turnover berpengaruh terhadap pertumbuhan laba.

\section{PEMBAHASAN}

Dalam penelitian ini yang meneliti pengaruh pertumbuhan laba dengan menggunakan debt to asset ratio (DAR), net profit margin (NPM), working capital to total assets (WCTA), inventory turnover (IT) sebagai variabel independen.Angka koefisien determinasi (Adjusted $R$ Square) adalah 0.020. Hal ini berarti $2.0 \%$ variasi dari LN PL dijelaskan oleh variasi dari keempat variabel independen, sedangkan sisanya $98.0 \%$ dijelaskan oleh variasi atau faktor di luar variabel yang digunakan. Dari persentase yang tergolong rendah tersebut menunjukkan bahwa masih terdapat pengaruh dari faktor lain yang tidak dimasukkan dalam penelitian ini. 


\section{KESIMPULAN DAN SARAN}

\section{Kesimpulan}

Berdasarkan hasil analisis data dan pembahasan telah diuraikan pada bab sebelumnya, maka dapat diambil kesimpulan sebagai berikut :

1. Secara parsial, debt to asset ratio tidak memiliki pengaruh signifikan terhadap pertumbuhan laba.

2. Secara parsial, net profit margin memiliki pengaruh signifikan terhadap pertumbuhan laba.

3. Secara parsial, working capital to total assets tidak memiliki pengaruh signifikan terhadap pertumbuhan laba.

4. Secara parsial, inventory turnover tidak memiliki pengaruh signifikan terhadap pertumbuhan laba.

5. Secara simultan, hasil penelitian ini menunjukkan bahwa debt to asset ratio, net profit margin, working capital to total assets, dan inventory turnover berpengaruh signifikan terhadap pertumbuhan laba.

\section{Saran}

Setelah mengkaji hasil penelitian dan keterbatasan yang dimiliki penulis, maka penulis menyarankan beberapa hal agar skripsi ini dapat disempurnakan adalah sebagai berikut

1. Penelitian selanjutnya disarankan untuk memperluas jenis perusahaan, misalnya perusahaan sektor barang konsumsi, sektor perbankan, sektor pertambangan dan lain sebagainya, sehingga pengujian yang dilakukan lebih berkualitas dan teruji dengan baik.

2. Penelitian selanjutnya disarankan untuk menambah jenis variabel independen sehingga akan memperjelas variabelvariabel yang akan mempengaruhi pertumbuhan laba. Variabel lainnya berupa quick ratio, ROA, ROE, dan rasio keuangan lainnya.
3. Penelitian selanjutnya disarankan untuk menggunakan jangka waktu yang lebih panjang, yaitu paling sedikit 5 tahun untuk menghasilkan pertumbuhan laba yang baik. 


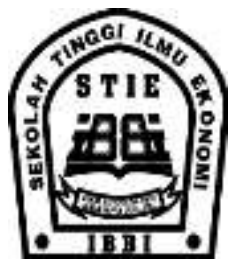

DAFTAR PUSTAKA

Anthony dan Govindarajan. 2005. Management

Control System. Edisi 11. Jakarta : Salemba Empat.

Ghozali, Imam. 2006. Aplikasi Analisis Multivariate dengan SPSS. Semarang: Badan Penerbit Universitas Diponegoro.

Harahap, Sofyan Syafri. 2004. Analisis Kritis

Laporan Keuangan. Jakarta: PT. Raja Grafindo Persada.

Harahap, Sofyan Syafri. 2005. Teori Akuntansi. Jakarta: PT. Raja Grafindo Persada.

Hartono, Jogiyanto. 2000. Analisis dan Desain Sistem Informasi : Pendekatan Terstruktur Teori dan Praktis Aplikasi bisnis. Yogyakarta: Andi.

Kasmir. 2009. Analisis Laporan Keuangan. Jakarta: Rajawali Pers.

Nasution,Sulfida Syahliza Amin. 2010. Pengaruh Rasio-rasio Keuangan TerhadapPertumbuhan Laba Pada Perusahaan Manufaktur Sektor Barang Konsumsi yang Terdaftar di Bursa Efek Indonesia. Medan: Universitas Sumatera Utara.

Putri, Thaussie Nurvigia Dwi Prabowo. 2010. Pengaruh Rasio-rasio Keuangan Terhadap Perubahan Laba Pada Perusahaan Otomotif yang Terdaftar di Bursa Efek Indonesia. Jakarta: Universitas Pembangunan Nasional

Veteran".

Sari, Tika Nurmala, 2011. Analisis Pengaruh Rasio Keuangan Terhadap Perubahan Laba Pada Perusahaan yang Terdaftar di
ISSN 1858-3202

JURNAL

BINA AKUNTANSI

IBBI

Bursa Efek Indonesia. Jakarta: Universitas Gunadarma.

Simamora, Henry. 2000. Akuntansi Basis Pengambilan Keputusan dan Bisnis. Jilid II. Jakarta: Salemba Empat.

Sumarni, Murti dan Salamah Wahyuni. 2006. Metodologi Penelitian Bisnis. Yogyakarta:

Penerbit Andi.

Suwardjono. 2005. Teori Akuntansi:

Perekayasaan Pelaporan Keuangan. Edisi III. Yogyakarta: BPFE.

Widiasih, Nur Ari. 2006. Analisis Rasio Keuangan Dalam Memprediksi Perubahan Laba Pada Perusahaan Manufaktur yang Terdaftar di Bursa Efek Jakarta (BEJ). Yogyakarta: Universitas Islam Indonesia.

Wild, John J., K. R. Subramanyam, dan Robert F. Hasley. 2005. Analisis Laporan Keuangan. Edisi 8. Jakarta: Salemba Empat.

www.idx.co.id 